\title{
FORMULASI BMC MENINGKATKAN KADAR PROTEIN KUE KERING DENGAN PENAMBAHAN TEPUNG IKAN
}

\author{
Lanita Somali, Sa'diah Multi Karina dan Endang Titi Amrihati \\ Politeknik Kesehatan Kemenkes Jakarta II \\ lanita_soemodihardjo@yahoo.com
}

\begin{abstract}
ABSTRAK
Protein hewani merupakan zat gizi yang baik untuk pertumbuhan tubuh dan mempunyai nilai biologi yang lebih tinggi dibanding dengan protein nabati. Oleh sebab itu dalam penelitian ini digunakan tepung ikan untuk meningkatkan protein score bahan dasar kue kering. Penelitian ini bertujuan untuk mengetahui pengaruh formula BMC tepung ikan terhadap kualitas organoleptik dan proksimat kue kering. Penelitian eksperimental dengan RAL 1 perlakuan, 6 taraf dan 3 replikasi diawali dengan menghitung PS $\geq 69$ berbagai formula BMC. Uji statistik menunjukkan tidak ada pengaruh berbagai formula terhadap warna, rasa, dan tekstur. Sebaliknya ada pengaruh berbagai formula terhadap aroma kue kering. Berdasarkan hasil penilaian panelis terhadap produk, panelis menyukai kue kering dengan perlakuan T-2, BMC dengan PS 81,2 mempunyai karakteristik: warna kuning keemasan, rasa cukup asin terasa gurih, renyah-kompak saat digigit dan sedikit beraroma ikan dengan 5,63\% kadar air, 1,91gram abu, 6,74gram protein, 29,47gram lemak dan 56,26 gram karbohidrat. Disarankan untuk mengembangkan kue kering dengan menggunakan tepung lain.
\end{abstract}

Keywords: protein score, BMC, kue kering, tepung ikan

\section{ABSTRACT}

\section{BMC FORMULATIONS INCREASE PROTEIN LEVEL COOKIES WITH ADDITION OF FISH FLOUR}

Animal protein is a good nutrient for the growth and has a higher biological value than vegetable protein. Therefore, in this study used fish flour to increase protein score as cookies ingredient. Accordingly, this study aimed to determine the effect of fish flour BMC formula to organoleptic quality and proximate in cookies. Experimental studies with RAL 1 treatment, 6 level and 3 replication were begun by calculating the PS $\geq 69$ of BMC. Statistical tests showed no effect of the various formulas for color, flavor, and texture. On the other hand, there was an effect of the various formulas in cookies flavor. Based on the results from the assessment panel of the product, they liked the cookies with the treatment of T-2, BMC with PS 81.2 had the following characteristics: golden yellow color, quite salty savory flavors, crisp and compact when bitten and somewhat flavorful fish with a $5.63 \%$ moisture content, ash 1.91 grams, 6.74 grams of protein, 29.47 grams of fat and carbohydrate 56.26 grams. It is suggested to develop cake flour with other mixture powder.

Keywords: protein score (PS), BMC, cookies, fish flour

\section{PENDAHULUAN}

K eberhasilan pembangunan suatu bangsa dapat diukur bukan hanya dari keberhasilan pembangunan fisik saja tetapi juga peranan pembangunan manusia yang sehat. Hubungan positif antara derajat kesehatan dengan tingkat produktifitas telah dibuktikan oleh berbagai studi. Gizi yang baik merupakan dasar tercapainya derajat kesehatan dan tingkat produktifitas tinggi seiring usaha mencapai Milenium Development Goals (MDGs). ${ }^{1}$ Masalah gizi merupakan salah satu faktor penentu tercapainya Millenium
Development Goals. ${ }^{1}$ Secara nasional berbagai jenis masalah gizi dialami 100 juta penduduk Indonesia. Gizi buruk masih diderita oleh sekitar 1.7 juta bayi dan anak balita. Sekitar 1.9 juta ibu hamil dan 8.8 juta balita menderita Anemia Gizi Besi (AGB). ${ }^{2}$

Pada Widya Karya Pangan dan Gizi (WNKPG) tahun 2004 dilaporkan bahwa banyaknya ikan yang ditangkap (darat dan laut) sekitar 6.26 juta ton per tahun. ${ }^{3}$ Setiap tahun konsumsi ikan per kapita/tahun meningkat sejak tahun 2005, 2006, 2007, 2008, 2010 berturutturut 23.95kg; 25.03kg; 26.03kg; 28kg; $30.47 \mathrm{~kg}$ menurut Kementerian Kelautan dan Perikanan. 
Tahun 2014 diperhitungkan menjadi 40.25 Kg/kapita/tahun. ${ }^{4}$ Pemasaran ikan selain dalam bentuk segar juga ada yang dikalengkan, dibekukan, diasin, didinginkan, diasap, diambil dagingnya saja (fillet) dan dibuat tepung yang kesemuanya bertujuan untuk memperpanjang masa simpan (shelf life) serta menaikkan nilai ekonomis ikan. $5,6,7$

Ikan selain sebagai sumber protein juga merupakan sumber kalsium yang baik khususnya ikan teri. Senyawa tri-kalsium fosfat mudah digunakan tubuh manusia dan merupakan kalsium yang ada dalam tulang ikan. Kalsium dibutuhkan manusia mulai dari janin sampai lanjut usia. Pada kondisi khusus seperti bumil dan busui dibutuhkan kalsium lebih banyak dari pada wanita biasa. Kebutuhan orang dewasa akan kalsium menurut Angka Kecukupan Gizi (AKG) 800mg/hari, anak 1018tahun $1000 \mathrm{mg}$, dan pada kondisi bumil dan busui meningkat menjadi $1050 \mathrm{mg}$. Berdasarkan WKNPG-2000 jumlah kalsium yang dikonsumsi rata-rata hanya 50\% AKG sejak tahun 1995, sedangkan asupan fosfor melebihi AKG. ${ }^{3}$ Tubuh dapat menjalankan fungsi dengan baik apabila rasio kalsium dan fosfor=1,5:1. Berdasarkan pemantauan pada tingkat rumah tangga konsumsi kalsium tahun 1993, 1996, 1999 dan 2002 sebesar 164,84; 326,14; 421,17 dan $331,74 \mathrm{mg} /$ kapita/hari. $^{2}$

Ikan merupakan sumber protein hewani yang baik untuk pertumbuhan tubuh dan dapat digunakan untuk mengatasi kekurangan protein khususnya pada balita. Khusus tepung ikan teri selain mengandung $48,8 \mathrm{gr} \%$ protein, juga mengandung $4608 \mathrm{mg} \%$ kalsium. Sedangkan kadar protein dan kalsium ikan teri basah berturut-turut $10,3 \mathrm{gr} \%$ dan $972 \mathrm{mg} \%{ }^{8}$

Kue kering merupakan salah satu produk yang disukai orang yang ditandai dengan meningkatnya produksinya dari $218.338 .512 \mathrm{~kg}$ pada tahun 2006 menjadi $306.109 .032 \mathrm{~kg}$ tahun 2007 menurut BPS. Kemenkes menetapkan kue kering/biscuit digunakan sebagai salah satu bentuk MPASI yang praktis dalam penanganan gizi buruk. Produk ini merupakan hasil pemanggangan adonan dengan bahan dasar tepung diperkaya dengan tambahan lemak, gula, atau garam dan bahan pengembang dengan kadar air akhir kurang dari 5 persen. Tepung yang digunakan dapat berupa campuran beberapa tepung yang diformulasikan untuk memenuhi syarat energi
$360 k$ kal, protein $16-20 \%$ dan lemak $25 \%$ dengan nilai biologi mencapai $\geq 69$ yang kemudian disebut Bahan Makanan Campuran (BMC). Formula BMC ini dapat digunakan sebagai bahan baku untuk membuat makanan bagi penderita gizi buruk ataupun untuk MPASI yang dalam studi ini dibuat kue kering.

Berdasarkan hal di atas studi ini bertujuan untuk mengetahui pengaruh formula BMC tepung ikan terhadap kualitas organoleptik dan proksimat kue kering. Oleh sebab itu perumusan masalah studi ini adalah bagaimanakah formulasi BMC tepung ikan ini terhadap warna, rasa, aroma, tekstur dan kadar protein, lemak, kabohidrat, air dan abu kue kering tersebut? Hipotesa penelitian secara keseluruhan ada perbedaan kualitas organoleptik dan daya terima kue kering yang dibuat dari berbagai formula BMC tepung ikan. Diharapkan studi ini dapat menyumbangkan pengembangan ilmu pengetahuan dan teknologi dengan ditemukannya formula dan teknik pembuatan kue kering yang mengandung nilai protein tinggi dengan protein score 69 atau lebih dan kualitas organoleptik yang dapat diterima konsumen (panelis). Produk mengandung protein dan kalsium tinggi yang baik untuk membantu menangani kasus gizi buruk selain merupakan salah satu alternatif diversifikasi dan inovasi pangan olahan dan peningkatan pendayagunaan ikan bagi penduduk khususnya nelayan.

\section{METODE PENELITIAN}

Penelitian eksperimental ini dibagi menjadi dua tahapan. Tahap pertama adalah mencari rasio tepung terigu dengan sagu yang cocok untuk dibuat kue kering. Rasio terigu dan sagu tersebut kemudian digunakan sebagai bahan untuk membuat formula BMC dengan ditambahkan tepung ikan. Formula BMC yang dihitung harus memenuhi 360 kkal, 16-20\% protein, $25 \%$ lemak dan memiliki PS $\geq 69$ atau lebih. Kemudian dipilih 6 formula yang mempunyai PS minimal 69. Penelitian tahap kedua adalah membuat kue kering dengan menggunakan 6 formula yang telah diperoleh dari tahap petama. Metode penelitian yang digunakan pada tahap kedua adalah metode percobaan dengan rancangan acak lengkap dengan pengulangan sebanyak tiga kali. Unit percobaan berjumlah 18 dihitung dengan rumus 
$\mathrm{n}=\mathrm{tx} \mathrm{r}$, t terdiri dari 6 formula dan pengulangan (r) 3 kali.

Pada studi ini digunakan bahan terigu, sagu yang diperoleh dari pasar Mayestik dan tepung ikan yang diperoleh dari Bali. Kue kering dibuat dengan menggunakan resep dasar kue kering yang telah dimodifikasi.

Uji kualitas organoleptik dilakukan di Laboratorium Pangan Politeknik Kesehatan Kemenkes Jakarta II, meliputi warna, rasa, aroma, tekstur dan tingkat kesukaan terhadap warna, rasa, aroma, tektur dan secara keseluruhan. Panelis menilai sampel kue kering yang dihidangkan di piring putih yang diberi kode sampel dan disusun secara acak sesuai disain lay out penelitian. Penilaian oleh panelis dilakukan dengan alat bantu formulir uji organoleptik. Produk kue kering yang paling diterima panelis akan diuji kadar protein, lemak, karbohidrat, abu dan air di laboratorium.

Data yang dikumpulkan meliputi hasil uji organoleptik warna, rasa, kerenyahan/tekstur dan aroma kue kering serta tingkat kesukaan serta data proksimat kue kering yang paling diterima panelis. Data organoleptik dapat dikumpulkan dengan menggunakan panelis. Jumlah panelis yang digunakan minimal 30 orang. Panelis yang digunakan harus memenuhi kriteria yang telah ditentukan dalam penelitian ini. Analisis proksimat yang meliputi kadar air, abu, protein, dan lemak akan dilakukan dengan menggunakan standar prosedur Association of Official Analytical chemistry (AOAC). Sedangkan karbohidrat dilakukan berdasarkan perhitungan.

Data organoleptik yang dikumpulkan kemudian ditabulasi dan dihitung rata-rata persentasenya. Untuk mengetahui adanya pengaruh berbagai formula BMC tepung ikan teri terhadap kualitas organoleptik dan daya terima dilakukan pengolahan data dengan Anova. Pengujian interaksi dilakukan dengan metode Duncan's Multiple Range Test (DMRT), apabila hasil uji beda bermakna secara statistik. Etik penelitian (eththical clearance) diajukan ke Komisi Etik Politeknik Kesehatan Kemenkes Jakarta II. Naskah penjelasan dibacakan ke panelis sebelum panelis melakukan penilaian dan jika panelis sudah setuju dengan keikutsertaannya, panelis diminta untuk menandatangani informed of consencel persetujuan setelah penjelasan(PSP).

\section{HASIL}

Rasio tepung terigu dengan sagu yang digunakan untuk menyusun formula BMC diperoleh dengan melakukan uji coba pembuatan kue kering dengan berbagai komposisi campuran tepung terigu dan sagu. Kue kering yang dihasilkan dari campuran tepung terigu dan sagu diamati tekstur, kerenyahan dan rasa sagu. Hasil uji coba dapat dilihat pada Tabel 1.

Dari hasil uji coba campuran tepung terigu dan tepung sagu, campuran 3 menghasilkan kue kering memenuhi kriteria: tekstur agak empuk, renyah dan sagu tidak terasa. Campuran tepung ini digunakan untuk menghitung protein score dari berbagai formula BMC yang merupakan campuran tepung terigu dan sagu dengan tepung ikan.

Berdasarkan hasil perhitungan dari 36 formula BMC diperoleh 6 formula yang digunakan dalam penelitian ini. Formula BMC dalam penelitian ini $\mathrm{T} 1, \mathrm{~T} 2, \mathrm{~T} 3, \mathrm{~T} 4, \mathrm{~T} 5$, dan $\mathrm{T} 6$ mempunyai protein score berkisar 69,8 - 93,4 dengan komposisi kimia dapat dilihat pada Tabel 2 yang dihitung berdasarkan Komposisi Zat Gizi dan Pangan Indonesia (KZGPI 1990).

Tabel 1

Hasil Uji Coba Campuran Tepung Terigu dan Tepung Sagu

\begin{tabular}{llllll}
\hline Bahan/Deskripsi & Campuran 1 & Campuran 2 & Campuran 3 & Campuran 4 & Campuran 5 \\
\hline Tepung Terigu & 100 gram & 95 gram & 90 gram & 85 gram & 80 gram \\
Tepung Sagu & 0 gram & 5 gram & 10 gram & 15 gram & 20 gram \\
Tekstur & Padat & Padat & Agak empuk & Mudah patah & Mudah patah \\
Kerenyahan & Kurang renyah & Kurang renyah & Renyah & Mudah hancur & Mudah hancr \\
Rasa sagu & Tidak terasa & Tidak terasa & Tidak terasa & Mulai terasa & Mulai teras \\
\hline
\end{tabular}


Dari hasil uji coba campuran tepung terigu dan tepung sagu, campuran 3 menghasilkan kue kering memenuhi kriteria: tekstur agak empuk, renyah dan sagu tidak terasa. Campuran tepung ini digunakan untuk menghitung protein score dari berbagai formula BMC yang merupakan campuran tepung terigu dan sagu dengan tepung ikan. Berdasarkan hasil perhitungan dari 36 formula BMC diperoleh 6 formula yang digunakan dalam penelitian ini. Formula BMC dalam penelitian ini T1, T2, T3, T4, T5, dan T6 mempunyai protein score berkisar 69,8 - 93,4 dengan komposisi kimia dapat dilihat pada Tabel 2 yang dihitung berdasarkan Komposisi Zat Gizi dan Pangan Indonesia (KZGPI 1990).

Tabel 2

Komposisi Kimia Formula BMC

\begin{tabular}{|c|c|c|c|c|c|c|}
\hline \multirow{2}{*}{ Deskripsi } & \multicolumn{6}{|c|}{ Formula BMC } \\
\hline & T-1 & T-2 & T-3 & $T-4$ & T-5 & T-6 \\
\hline Berat BMC & 100 & 100 & 100 & 100 & 100 & 100 \\
\hline Kal & 364,1 & 364,1 & 364 & 364 & 363,9 & 363,9 \\
\hline Protein & 8,18 & 8,65 & 9,25 & 9,75 & 10,25 & 10,75 \\
\hline Lemak & 10,8 & 10,9 & 10,9 & 11 & 11 & 11,1 \\
\hline Karbohidrat & 74,7 & 74,1 & 73,6 & 73,1 & 72,6 & 72,1 \\
\hline Abu & 0,93 & 1 & 1 & 1,1 & 1,2 & 1,2 \\
\hline Air & 15,4 & 15,3 & 15,2 & 15,1 & 14,9 & 14,8 \\
\hline Kalsium & 22,5 & 54,2 & 86 & 117,7 & 149,4 & 181,2 \\
\hline PS & 69,8 & 81,2 & 85,2 & 88,2 & 91,1 & 93,4 \\
\hline
\end{tabular}

\section{Uji Organoleptik}

Kue kering dibuat berdasarkan hasil perhitungan protein score yang diperoleh 6 formula tepung BMC. Produk kue kering dari 6 formulasi dengan 3 replikasi tersebut kemudian diuji organoleptik oleh 30 orang panelis. Uji cita rasa terhadap kue kering yang dibuat tersebut meliputi warna, rasa, tekstur dan aroma dipaparkan pada Tabel 3.

Dalam hal warna, persentase terbesar penilaian panelis untuk warna kue kering pada perlakuan T1, T2 dan T3 adalah kuning keemasan (berturut-turut 88\%, 69\% dan 43\%). Penilaian terbanyak untuk warna kue kering pada T4 (34\%) dan T5 (38\%) adalah coklat muda. Penilaian terbesar untuk kue kering T-6 (32\%) jatuh pada coklat tua. Berdasarkan analisis statistik Anova yang dilakukan dengan tingkat kepercayaan 95\% diperoleh $\mathrm{Fc}=81,66$ dan $\mathrm{Ft}=2,21$. Hal ini menunjukkan bahwa nilai pada tabel untuk Fc>Ft yang berarti Ho ditolak dan Ha diterima. Analisis statistik Duncan's Mulitiple Range Test (DMRT) menyatakan ada pengaruh yang signifikan antara $\mathrm{T} 1$ dengan $\mathrm{T} 2$, T3, T4, T5, T6 ; T2 dengan T3, T4, T5, T6; T3 dengan T4, T5; dan T4 dengan T5. Sedangkan $\mathrm{T} 6$ dengan $\mathrm{T} 3, \mathrm{~T} 4, \mathrm{~T} 5$ tidak signifikan.

Dari segi rasa, persentase terbesar penilaian panelis untuk rasa kue kering pada semua perlakuan T1, T2, T3, T4, T5 dan T6 (berturut-turut 23\%, 27\%, 28\%,33\%, 38\%, dan $36 \%$ ) adalah cukup asin terasa gurih, walaupun pada perlakuan T1 terlihat persentase yang sama besarnya untuk deskripsi tidak asin terasa gurih (23\%). Berdasarkan analisis statistik Anova yang dilakukan dengan tingkat kepercayaan $95 \%$ diperoleh $\mathrm{Fc}=1,3$ dan $\mathrm{Ft}=$ 2,53. Hal ini menunjukkan bahwa nilai $\mathrm{Fc}<\mathrm{Ft}$ yang berarti tidak signifikan. Dengan demikian berarti Ho diterima. Analisis statistik menyatakan tidak ada pengaruh berbagai formulasi BMC tepung ikan yang digunakan terhadap rasa kue kering, yang juga didukung dengan data persentase yang tertera pada Tabel 3.

Dari segi tekstur, persentase terbesar penilaian panelis untuk tekstur kue kering pada perlakuan T1 dan T2 adalah renyah dan kompak saat digigit (berturut-turut $27 \%$ dan $26 \%$ ). Penilaian terbanyak untuk tekstur kue 
kering pada T3 (22\%) yaitu agak keras dan mudah hancur. Sedangkan persentase tertinggi unyuk perlakuan T4, T5 dan T6 adalah renyah dan mudah hancur saat digigit (berturut-turut $50 \%$, 61\% dan 39\%). Berdasarkan analisis statistik Anova yang dilakukan dengan tingkat kepercayaan 95\% diperoleh nilai $\mathrm{Fc}=39,2$ dan $\mathrm{Ft}=2,21$. Hal ini menunjukkan bahwa nilai $\mathrm{Fc}>\mathrm{Ft}$ yang berarti tidak bermakna. Dengan demikian berarti Ho ditolak dan Ha diterima. Analisis statistik menyatakan ada pengaruh yang bermakna berbagai formulasi BMC tepung ikan yang digunakan terhadap tekstur kue kering, kecuali formulasi T1-T2 dan T4-T5 yang menunjukkan tidak bermakna.

Tabel 3

Persentase Uji Cita Rasa Kue Kering Dengan Berbagai Formula

\begin{tabular}{lcccccc}
\hline \multirow{2}{*}{\multicolumn{1}{c}{ Deskripsi }} & \multicolumn{7}{c}{ Formula } \\
\cline { 2 - 8 } & T-1 & T-2 & T-3 & T-4 & T-5 & T-6 \\
\hline Warna & 88 & 69 & 43 & 10 & 4 & 10 \\
Kuning keemasan & 3 & 10 & 14 & 32 & 32 & 28 \\
Coklat & 8 & 20 & 32 & 38 & 34 & 30 \\
Coklat muda & 1 & 1 & 10 & 20 & 29 & 32 \\
Coklat tua & 23 & 13 & 18 & 23 & 11 & 11 \\
\hline Rasa & 23 & 27 & 28 & 33 & 38 & 36 \\
Tidak asin terasa gurih & 22 & 21 & 22 & 21 & 30 & 26 \\
Cukup asin terasa gurih & 14 & 22 & 16 & 7 & 10 & 11 \\
Agak asin terasa gurih & 6 & 7 & 9 & 19 & 8 & 9 \\
Tidak asin tidakgurih & 11 & 10 & 8 & 5 & 3 & 8 \\
Cukup asin tidak gurih & & & & & & \\
Agak asin tidak gurih & 20 & 14 & 7 & 50 & 61 & 39 \\
\hline Tekstur & 27 & 26 & 21 & 34 & 26 & 27 \\
Renyah dan mudah hancur saat digigit & 24 & 20 & 22 & 8 & 4 & 20 \\
Renyah \& kompak saat digigit & 13 & 23 & 21 & 4 & 1 & 8 \\
Agak keras \& mudah hancur saat digigit & 2 & 3 & 11 & 2 & 3 & 3 \\
Agak Keras dan kompak saat digigit & 13 & 13 & 18 & 1 & 4 & 3 \\
Keras dan mudah hancur saat digigit & 74 & 36 & 12 & 6 & 3 & 7 \\
Keras dan kompak saat digigit & 18 & 48 & 39 & 29 & 14 & 20 \\
\hline Aroma & 4 & 13 & 37 & 37 & 39 & 28 \\
Tidak beraroma ikan & 3 & 3 & 12 & 29 & 43 & 46 \\
Agak beraroma ikan & & & & & \\
Beraroma ikan & Sangat beraroma ikan &
\end{tabular}

Dalam hal aroma pada produk, persentase terbesar penilaian panelis untuk aroma kue kering pada perlakuan $\mathrm{T} 1$ (74\%) adalah tidak beraroma ikan. Aroma kue kering T2 (48\%) dan T3 (39\%) adalah agak beraroma ikan. Kue kering T4 (37\%) adalah beraroma ikan. Aroma produk kue kering T6 (46\%) adalah sangat beraroma ikan. Berdasarkan analisis statistik Anova yang dilakukan dengan tingkat kepercayaan 95\% diperoleh $\mathrm{Fc}=106,0$ dan $\mathrm{Ft}=$ 2,21. Hal ini menunjukkan bahwa nilai $\mathrm{Fc}>\mathrm{Ft}$ yang berarti signifikan. Dengan demikian berarti Ho tidak diterima dan Ha diterima. Analisis statistik menyatakan ada pengaruh berbagai formulasi BMC tepung ikan yang digunakan terhadap aroma kue kering, yang juga didukung dengan data persentase yang tertera pada Tabel 3. Analisis stastitik menyatakan ada pengaruh yang bermakna antar perlakuan kecuali pada T5-T6 dan T5-T4 yang menunjukkan tidak bermakna.

\section{Tingkat Kesukaan}

Penilaian tingkat kesukaan dapat dilihat pada Tabel 4. Penilaian panelis terhadap tingkat kesukaan warna kue kering menunjukkan bahwa presentase terbesar pada T1 dan T2 menyatakan suka (52\% dan $63 \%$ ). Sedangkan presentase tertinggi yang menyatakan tidak suka terhadap warna adalah pada kue kering dengan formulasi T6 (39\%). Berdasarkan analisis statistik Anova yang dilakukan dengan 
tingkat kepercayaan 95\% diperoleh $\mathrm{Fc}=59,6$ dan $\mathrm{Ft}=2$ 221. Hal ini menunjukkan bahwa nilai $\mathrm{Fc}>\mathrm{Ft}$ yang berarti ada pengaruh yang bermakna terhadap tingkat kesukaan warna dengan berbagai formulasi. Dengan demikian berarti $\mathrm{Ho}$ tidak diterima dan $\mathrm{Ha}$ diterima.
Analisis statistik untuk tingkat kesukaan warna produk menyatakan ada pengaruh yang bermakna pada antar formulasi BMC tepung ikan kecuali pada T1-T2, T4-T5, T4-T6 dan T5T6 yang menunjukkan tidak bermakna.

Tabel 4

Persentase Tingkat Kesukaan Kue Kering dengan Berbagai Formula

\begin{tabular}{lcccccc}
\hline \multirow{2}{*}{ Tingkat Kesukaan } & \multicolumn{7}{c}{ Formula } \\
\cline { 2 - 7 } & T-1 & T-2 & T-3 & T-4 & T-5 & T-6 \\
\hline Warna & 2 & 6 & 15 & 27 & 39 & 39 \\
Tidak suka (1) & 13 & 19 & $\mathbf{4 0}$ & $\mathbf{4 7}$ & $\mathbf{4 1}$ & 39 \\
Agak suka (2) & $\mathbf{5 2}$ & $\mathbf{6 3}$ & 32 & 25 & 16 & 20 \\
Suka (3) & 33 & 12 & 13 & 1 & 4 & 2 \\
Sangat suka (4) & & & & & & \\
\hline Rasa & 22 & 29 & 33 & 23 & 24 & 39 \\
Tidak suka (1) & 29 & 32 & 37 & 40 & 34 & 42 \\
Agak suka (2) & 39 & 29 & 24 & 29 & 34 & 16 \\
Suka (3) & 10 & 10 & 6 & 8 & 7 & 3 \\
Sangat suka (4) & & & & & & \\
\hline Tekstur & 27 & 27 & $\mathbf{4 2}$ & 7 & 9 & 12 \\
Tidak suka (1) & 33 & $\mathbf{4 9}$ & 38 & 39 & 23 & $\mathbf{4 6}$ \\
Agak suka (2) & 32 & 18 & 18 & 32 & $\mathbf{4 0}$ & 30 \\
Suka (3) & 8 & 7 & 2 & 22 & 28 & 12 \\
Sangat suka (4) & & & & & & \\
\hline Aroma & 9 & 17 & 33 & $\mathbf{4 4}$ & $\mathbf{5 1}$ & $\mathbf{5 4}$ \\
Tidak suka (1) & 24 & $\mathbf{4 9}$ & $\mathbf{5 2}$ & 40 & 36 & 32 \\
Agak suka (2) & $\mathbf{4 1}$ & 24 & 11 & 14 & 11 & 12 \\
Suka (3) & 26 & 10 & 3 & 1 & 2 & 1 \\
Sangat suka (4) & & & & & & \\
\hline Umum & 24 & 18 & 34 & 24 & 30 & 39 \\
Tidak suka (1) & 36 & 18 & $\mathbf{4 7}$ & $\mathbf{4 2}$ & 39 & $\mathbf{4 1}$ \\
Agak suka (2) & 31 & $\mathbf{4 3}$ & 17 & 26 & 27 & 18 \\
Suka (3) & 9 & 21 & 2 & 8 & 4 & 2 \\
\hline Sangat suka (4) & & & & &
\end{tabular}

Penilaian panelis terhadap tingkat kesukaan terhadap rasa kue kering menunjukkan bahwa presentase terbesar pada T1 dan T4 menyatakan suka (39\% dan 34\%). Sedangkan presentase tertinggi yang menyatakan tidak suka terhadap rasa adalah pada kue kering dengan formulasi T6 (39\%). Berdasarkan analisis statistik Anova yang dilakukan dengan tingkat kepercayaan 95\% diperoleh $\mathrm{Fc}=4,8$ dan $\mathrm{Ft}=2,21$. Hal ini menunjukkan bahwa $\mathrm{Fc}>\mathrm{Ft}$ yang berarti ada pengaruh yang bermakna terhadap tingkat kesukaan rasa dengan berbagai formulasi. Dengan demikian berarti Ho tidak diterima dan $\mathrm{Ha}$ diterima. Analisis statistik DMRT untuk tingkat kesukaan rasa produk menyatakan ada pengaruh yang bermakna pada antar formulasi BMC tepung ikan kecuali pada T1-T4, T1-T5, T1-T2, T4-T5, T4-T2, T4-T3, T5-T2, T5-T3, T2T3 dan T3-T6 yang menunjukkan tidak bermakna.

Penilaian panelis terhadap tingkat kesukaan terhadap tekstur kue kering menunjukkan bahwa presentase terbesar pada T5 menyatakan suka (40\%), sedangkan presentase tertinggi yang menyatakan tidak suka terhadap tekstur adalah pada kue kering dengan formulasi T3 (42\%). Empat dari enam perlakuan menyatakan agak suka dengan persentase tertinggi yaitu T1, T2, T4 dan T6 
yaitu 33 persen, 49 persen, 39 persen dan 46 persen. Berdasarkan analisis statistik Anova yang dilakukan dengan tingkat kepercayaan 95\% diperoleh $\mathrm{Fc}=25,4$ dan $\mathrm{Ft}=2,21$. Hal ini menunjukkan bahwa $\mathrm{Fc}>\mathrm{Ft}$ yang berarti ada pengaruh yang bermakna terhadap tingkat kesukaan tekstur dengan berbagai formulasi. Dengan demikian berarti Ho tidak diterima dan $\mathrm{Ha}$ diterima. Analisis statistik DMRT untuk tingkat kesukaan rasa produk menyatakan ada pengaruh yang bermakna pada antar formulasi BMC tepung ikan kecuali pada T5-T4, T6-T1, dan T1-T2 yang menunjukkan tidak bermakna.

Penilaian panelis terhadap tingkat kesukaan terhadap aroma kue kering menunjukkan bahwa presentase terbesar pada T1 dan T2 menyatakan suka ( $41 \%$ dan $24 \%$ ) serta agak suka pada T2 dan T3 (49\% dan $52 \%)$. Sedangkan presentase tertinggi yang menyatakan tidak suka terhadap aroma kue kering adalah pada formulasi T4 (44\%), T5 (51\%), dan T6 (54\%). Berdasarkan analisis statistik Anova yang dilakukan dengan tingkat kepercayaan $95 \%$ diperoleh nilai $\mathrm{Fc}=43,2$ dan $\mathrm{Ft}=2,21$. Hal ini menunjukkan bahwa $\mathrm{Fc}>\mathrm{Ft}$ yang berarti ada pengaruh yang bermakna terhadap tingkat kesukaan aroma dengan berbagai formulasi. Dengan demikian berarti Ho tidak diterima dan $\mathrm{Ha}$ diterima. Analisis statistik DMRT untuk tingkat kesukaan aroma produk menyatakan ada pengaruh yang bermakna pada antar formulasi BMC tepung ikan kecuali pada T3-T4, T3-T5, T4-T5, T4-T6 dan T5-T6 yang secara statistik tidak bermakna.

Penilaian panelis terhadap tingkat kesukaan secara umum kue kering menunjukkan bahwa presentase terbesar pada T1 dan T2 menyatakan suka (31\% dan $43 \%$ ). Sedangkan presentase tertinggi yang menyatakan tidak suka terhadap rasa adalah pada kue kering dengan formula T6 (39\%). Dari penilaian panelis lima dari enam perlakuan ternyata memperoleh persentase tertinggi pada komponen agak suka yaitu T1 (36\%), T3 (47\%), T4 (42\%), T5 (39\%) dan T6 (41\%). Berdasarkan analisis statistik Anova yang dilakukan dengan tingkat kepercayaan $95 \%$ diperoleh nilai $\mathrm{Fc}=14,4$ dan $\mathrm{Ft}=2,21$. Hal ini menunjukkan bahwa Fc>Ft yang berarti ada pengaruh yang bermakna terhadap tingkat kesukaan umum produk dengan berbagai formulasi. Dengan demikian berarti $\mathrm{Ho}$ tidak diterima dan $\mathrm{Ha}$ diterima. Analisis statistik DMRT untuk tingkat kesukaan umum produk menyatakan ada pengaruh yang bermakna pada antar formulasi BMC tepung ikan kecuali pada T2-T4, T2-T5, T4-T5, T5-T3, T5-T6 dan T3-T6 yang mana menunjukkan tidak bermakna.

Tabel 5

Komposisi Kimia Tepung BMC, Adonan, Kue Kering

\begin{tabular}{lcccccc}
\hline \multirow{2}{*}{ Komposisi Kimia } & \multicolumn{2}{c}{$\begin{array}{c}\text { KZGI 1990 } \\
\text { Tepung }\end{array}$} & \multicolumn{2}{c}{$\begin{array}{c}\text { Adonan Kue } \\
\text { Kering }\end{array}$} & \multicolumn{2}{c}{$\begin{array}{c}\text { Hasil Uji Lab } \\
\text { Kue Kering }\end{array}$} \\
\cline { 2 - 8 } & T-1 & T-2 & T-1 & T-2 & T-1 & T-2 \\
\hline Berat & 100 & 100 & 100 & 100 & 100 & 100 \\
Enerji (Kal) & 364,1 & 364,1 & 482,7 & 482,7 & 526,94 & 517,23 \\
Protein (gr) & 8,18 & 8,65 & 5,7 & 6,0 & 6,49 & 6,74 \\
Lemak (gr) & 10,8 & 10,9 & 30,9 & 30,9 & 29,66 & 29,47 \\
Karbohidrat (gr) & 74,7 & 74,1 & 49,9 & 49,5 & 58,51 & 56,26 \\
Abu (\%) & 0,93 & 1 & - & - & 1,77 & 1,91 \\
Air (\%) & 15,4 & 15,3 & 20,6 & 20,6 & 3,57 & 5,63 \\
Kalsium & 22,5 & 54,2 & 21,7 & 42,8 & - & - \\
PS & 69,8 & 81,2 & - & - & - & - \\
\hline
\end{tabular}

\section{Kadar Proksimat.}

Uji proksimat dilakukan terhadap produk kue kering terpilih yaitu T2 dan yang tanpa penambahan tepung ikan (T1). Tabel 5 menunjukkan kadar proksimat, meliputi kadar air $(5,6 \%)$, abu $(2,8 \%)$, protein $(6,74 \mathrm{~g})$, lemak $(29,5 \mathrm{~g})$ dan karbohidrat $(56,3 \mathrm{~g})$ dari produk kue 
kering T-2 yang terpilih oleh panelis. Proksimat juga dilakukan terhadap T-1 kue kering dengan hasil kadar air $(3,57 \%)$, abu $(1,8 \%)$, protein $(6,49 \mathrm{~g})$, lemak $(29,7 \mathrm{~g})$ dan karbohidrat $(58,5 \mathrm{~g})$ sebagai pembanding. Dalam Standar Nasional Indonesia (SNI) biskuit kadar air maksimal 5 persen, protein 6,5 persen dan abu 1,5 persen.

\section{BAHASAN}

Hasil uji coba pada tahap pertama diperoleh rasio tepung terigu: sagu adalah 9:1. Kue kering yang dihasilkan pada rasio ini bertekstur agak empuk, renyah dan rasa sagu tidak terdeteksi oleh panelis (Tabel 1). Makin tinggi rasio sagu, kue kering yang dihasilkan menjadi mudah patah dan hancur. Penambahan tepung sagu menghasilkan kue kering yang lebih empuk dan renyah. Hal ini dapat dimengerti karena tepung sagu mengandung karbohidrat amylopektin lebih banyak dari tepung terigu. Disamping itu makin tinggi tepung terigu, kue kering yang dihasilkan bertekstur makin padat. Hal ini disebabkan karena tepung terigu mengandung gluten. Gluten memberikan adonan menjadi elastis memberikan produk panggang bertekstur padat.

Komposisi kimia formula BMC dihitung berdasarkan Komposisi zat gizi pangan Indonesia dan diperoleh 6 formulasi yang digunakan pada penelitian ini. Formulasi BMC yang digunakan mempunyai komposisi kimia untuk energi 362,9-364,1 kkal, protein 8,1810,75 gram, lemak 10,8-11 gram, karbohidrat 72,1-74,7 gram dan protein score 69,8-93,4. BMC yang digunakan dalam penelitian ini mempunyai protein score yang sesuai dengan persyaratan minimal BMC yaitu $\geq 69$. Syarat komposisi kimia BMC adalah 360 kkal, 16-20\% protein, $25 \%$ lemak dan memiliki skor protein $\geq 69$. Ke-enam formula BMC pada penelitian ini memenuhi persyaratan tersebut kecuali kadar proteinnya hanya mencapai $8,9-12,2 \%$ dari total energi. Walaupun demikian mutu protein dari formula BMC yang digunakan sudah mencapai minimal $\geq 69$.

\section{Uji Organoleptik}

Persentase tertinggi warna kue kering kuning keemasan pada $\mathrm{T} 1, \mathrm{~T} 2$ dan $\mathrm{T} 3$ berturutturut $88 \%, 69 \%$ dan $43 \%$. Diikuti dengan warna coklat muda untuk T4 (34\%) dan T5 (38\%), serta warna coklat untuk T6. Disini terlihat bahwa ada kecenderungan makin banyak penambahan tepung ikan maka warna kue kering bergeser dari warna kuning keemasan ke coklat tua. Hal ini dapat dimaklumi karena warna dasar tepung ikan berwarna coklat. Analisis statistik menunjukan bahwa nilai $\mathrm{Fc}>\mathrm{Ft}$ yang berarti ada pengaruh berbagai perlakuan formulasi terhadap warna. Secara deskriptif terlihat adanya kecenderungan makin bertambah konsentrasi tepung ikan, produk kue kering cendrung bertambah coklat. Hal ini didukung dengan analisis statistik memang ada perbedaan yang bermakna dari berbagai formula BMC dimana jumlah tepung ikannya berbeda.

Penilaian untuk rasa kue kering adalah cukup asin terasa gurih, walaupun pada perlakuan T1 terlihat persentase yang sama besarnya untuk deskripsi tidak asin terasa gurih (23\%). Disini terlihat bahwa tidak ada kecenderungan makin banyak penambahan tepung ikan maka rasa kue kering berubah. Analisis statistik menunjukkan nilai $\mathrm{Fc}<\mathrm{Ft}$ yang berarti tidak signifikan, Ho diterima artinya tidak ada pengaruh berbagai perlakuan formulasi terhadap rasa. Penambahan karena tepung ikan yang digunakan adalah tawar, sehingga kue kering dengan rasa asin dan gurih tidak dipengaruhi oleh penambahan tepung ikan.

Tekstur kue kering renyah dan kompak saat digigit untuk perlakuan T1 $(27 \%)$ dan T2 (26\%), pada T3 tekstur agak keras dan mudah hancur, T4, T5 dan T6 adalah renyah dan mudah hancur saat digigit. Analisa statistik menunjukkan bahwa nilai $\mathrm{Fc}>\mathrm{Ft}$ yang berarti tidak bermakna, Ho ditolak dan $\mathrm{Ha}$ diterima yang berarti ada pengaruh berbagai formulasi BMC tepung ikan terhadap tekstur kue kering.

Kue kering tidak beraroma ikan pada perlakuan T1 (74\%), agak beraroma ikan pada T2 (48\%) dan T3 (39\%). Aroma ikan lebih nyata pada T4 (37\%) dan sangat beraroma ikan pada T6 (46\%). Terlihat disini ada kecenderungan makin banyak penambahan tepung ikan maka produk kue kering aroma ikan lebih terasa. Hal ini didukung dengan hasil analisa statistik yang menunjukkan nilai $\mathrm{Fc}>\mathrm{Ft}$ yang berarti bermakna, Ho tidak diterima artinya ada pengaruh berbagai perlakuan formulasi terhadap aroma kue kering oleh panelis. 


\section{Tingkat Kesukaan}

Data menunjukkan bahwa tingkat kesukaan terhadap warna ke kering menyatakan suka pada T1 dan T2 (52\% dan 63\%). Sedangkan presentase tertinggi yang menyatakan tidak suka terhadap warna adalah pada kue kering dengan formulasi T6 (39\%). Dari komponen tidak suka terhadap warna terlihat adanya kecenderungan meningkat dengan makin tinggi penambahan tepung ikan, yaitu dari 2 persen, 6 persen, 15 persen 27 persen, 39 persen dan 39 persen untuk T1. T2, T3, T4, T5, dan T6. Hal ini didukung dengan hasil uji satatistik yang menyatakan nilai $\mathrm{Fc}>\mathrm{Ft}$, Ho tidak diterima artinya ada pengaruh berbagai perlakuan formulasi terhadap tingkat kesukaan warna kue kering oleh panelis.

Tingkat kesukaan terhadap rasa kue kering pada T1 dan T4 menyatakan suka (39\% dan $34 \%$ ). Sedangkan presentase tertinggi yang menyatakan tidak suka terhadap rasa adalah pada kue kering dengan formulasi T6 (39\%). Komponen tidak suka terhadap rasa terlihat adanya kecenderungan meningkat dengan makin tinggi penambahan tepung ikan, yaitu dari 22 persen, 29 persen, 33 persen, 23 persen, 24 persen dan 39 persen untuk T1. T2, T3, T4, T5, dan T6. Hal ini didukung dengan hasil uji satatistik yang menyatakan nilai $\mathrm{Fc}>\mathrm{Ft}$, Ho tidak diterima artinya ada pengaruh berbagai perlakuan formulasi terhadap tingkat kesukaan rasa kue kering oleh panelis.

Data tingkat kesukaan terhadap tekstur kue kering menunjukkan T5 menyatakan suka $(40 \%)$ dan tidak suka terhadap tekstur pada formulasi T3 (42\%). Empat dari enam perlakuan menyatakan agak suka dengan persentase tertinggi yaitu $T 1, T 2, T 4$ dan $T 6$ yaitu 33 persen, 49 persen, 39 persen dan 46 persen. Data menujukkan adanya pengaruh penambahan tepung ikan terhadap tekstur kue kering. Hal ini didukung oleh hasil analisa statistik yang menunjukkan bahwa $\mathrm{Fc}>\mathrm{Ft}$ yang berarti ada pengaruh yang signifikan atau bermakna terhadap tingkat kesukaan tekstur dengan berbagai formulasi. Dengan demikian berarti Ho tidak diterima dan Ha diterima artinya ada pengaruh berbagai perlakuan formulasi terhadap tingkat kesukaan tekstur kue kering oleh panelis.

Tabel 5

Persentase Suka dan Tidak Suka Panelis Terhadap Produk

\begin{tabular}{ccccccc}
\hline \multirow{2}{*}{ Perlakuan } & \multicolumn{2}{c}{ Suka } & \multicolumn{2}{c}{ Tidak Suka } & \multicolumn{2}{c}{ Jumlah } \\
\cline { 2 - 7 } & $\mathrm{n}$ & $\%$ & $\mathrm{n}$ & $\%$ & $\mathrm{n}$ & $\%$ \\
\hline T-1 & 68 & 76 & 16 & 18 & 90 & 100 \\
T-2 & 74 & $\mathbf{8 2}$ & 22 & 24 & 90 & 100 \\
T-3 & 59 & 66 & 31 & 34 & 90 & 100 \\
T-4 & 68 & 75 & 22 & 25 & 90 & 100 \\
T-5 & 63 & 70 & 27 & 30 & 90 & 100 \\
T-6 & 55 & 61 & 35 & 39 & 90 & 100 \\
\hline
\end{tabular}

Data tingkat kesukaan terhadap aroma kue kering menunjukkan T1 dan T2 menyatakan suka ( $41 \%$ dan $24 \%$ ), agak suka pada T2 dan T3 (49\% dan 52\%). Sedangkan yang menyatakan tidak suka terhadap aroma kue kering adalah pada formulasi T4 (44\%), T5 (51\%), dan T6 (54\%). Dari komponen tidak suka terhadap aroma kue kering terlihat adanya kecenderungan meningkat dengan makin tinggi penambahan tepung ikan, yaitu dari 9 persen, 17 persen, 33 persen, 44 persen, 51 persen dan 54 persen untuk T1. T2, T3, T4, T5, dan T6. Hal ini didukung oleh hasil analisa statistik yang menunjukkan bahwa $\mathrm{Fc}>\mathrm{Ft}$ yang berarti ada pengaruh yang signifikan atau bermakna terhadap tingkat kesukaan aroma dengan berbagai formulasi. Dengan demikian berarti Ho tidak diterima dan $\mathrm{Ha}$ diterima artinya ada pengaruh berbagai perlakuan formulasi terhadap tingkat kesukaan aroma kue kering oleh panelis.

Data tingkat kesukaan secara umum terhadap produk kue kering diolah dengan mengkategorikan menjadi dua kelompok yaitu 
suka dan tidak suka. Data dari komponen sangat suka, suka dan agak suka dikategorikan masuk ke kelompok "Suka". Sedangkan komponen tidak suka masuk kategori "Tidak Suka". Dari Tabel 5 terlihat bahwa penilaian panelis terhadap kesukaan produk kue kering menunjukkan bahwa pada umumnya produk kue kering disukai oleh panelis. Produk T-1 (83\%) yaitu produk tanpa tepung ikan memperoleh persentase tertinggi. Sedangkan produk kue kering yang menggunakan tepung ikan jatuh pada perlakuan T-2 (76\%). Berdasarkan data tersebut maka produk kue kering dengan penambahan tepung ikan yang terpilih adalah perlakuan T-2 dengan kriteria: warna kuning keemasan, rasa cukup asin terasa gurih, renyah dan kompak saat digigit, agak beraroma ikan.

Kadar proksimat produk kue kering T2 adalah 5,63 persen air; 1,91 persen abu; 6,74 gram protein; 29,47 gram lemak dan 56.26 gram karbohidrat. Menurut SNI kadar air, protein dan abu maksimal adalah 5 persen; 6,5 persen dan 1,5 persen. Dibandingkan dengan SNI, kadar abu produk T-2 yang dihasilkan lebih tinggi. Hal ini dimungkinkan karena dengan penambahan tepung ikan, kadar mineral kue kering menjadi meningkat. Kadar protein T-2 terlihat lebih tinggi dibanding dengan SNI. Sedangkan kadar protein pada T-1 lebih rendah dibandingkan dengan SNI dan T-2. Hal ini dimungkinkan karena adanya penambahan tepung ikan pada T-2. Sedangkan T-1 lebih rendah kadar proteinnya disebabkan karena tidak ada tambahan tepung ikan dan telur. Kadar air yang lebih tinggi dapat diantisipasi dengan waktu pemanggangan yang lebih lama. Produk ternyata mempunyai kadar protein lebih tinggi. Hal ini lebih baik dan cocok untuk konsumsi anak balita yang membutuhkan protein. Sedangkan kadar abu mencerminkan adanya kandungan mineral. Dengan lebih tingginya kadar abu maka diharapkan kadar mineralnya juga lebih tinggi seperti kadar kalsium.

\section{SIMPULAN DAN SARAN}

\section{Simpulan}

Enam formula Bahan Makanan Campuran (BMC) tepung ikan dalam penelitian ini mempunyai protein score berkisar dari 69,8 sampai dengan 93,4. Analisis statistik Anova dengan tingkat kepercayaan 95\% menyatakan ada pengaruh berbagai formula BMC yang bermakna terhadap kualitas organoleptik kue kering meliputi warna, tekstur dan aroma. Untuk rasa, uji statistik menghasilkan tidak ada pengaruh. Tepung ikan mengandung protein. Protein dalam pengolahan akan mengalami proses browning. Oleh sebab itu makin tinggi kandungan protein/ tepung ikan dalam BMC, maka akan berpengaruh terhadap warna produk. Protein yag berasal dari daging atau ikan jika dipanggang atau digoreng akan menjadi renyah/garing. Oleh sebab itu tepung ikan dalam formula BMC mempengaruhi tekstur kue kering yang dihasilkan. Tepung ikan yang digunakan dalam formula BMC mempunyai aroma ikan yang menyengat. Warna tepung ikan coklat. Oleh sebab itu aroma kue keringpun sangat dipengaruhi dengan bertambahnya kadar tepung ikan yang dicampur dalam BMC. Sedangkan rasa kue kering ternyata tidak dipengaruhi oleh penambahan tepung ikan.

Daya terima panelis terhadap kue kering dinyatakan dengan tingkat kesukaan hedonik. Hasil analisis statistik menyatakan ada pengaruh terhadap tingkat kesukaan warna, rasa, tekstur dan aroma. Penilaian panelis terhadap tingkat kesukaan produk kue kering secara umum menunjukkan ada pengaruh yang bermakna. Persentase "suka" terhadap produk kue kering yang dibuat dengan formula BMC tepung ikan adalah produk T2 yaitu 76 persen dengan kriteria warna kuning keemasan, rasa cukup asin terasa gurih, tekstur renyah dan kompak saat digigit serta agak beraroma ikan.

Ternyata pada produk T2 mempunyai kadar protein lebih tinggi daripada produk lain, sehingga cocok untuk konsumsi anak balita yang membutuhkan protein untuk pertumbuhan.

\section{Saran}

Mengingat produk makanan kecil yang mengandung nilai gizi yang bermutu sangat diperlukan terutama untuk anak baita, anak sekolah, ibu hamil, dan ibu menyusui, maka penelitian seperti ini perlu dilakukan lagi pada campuran bahan makanan lain, agar memperoleh banyak variasi makanan kecil yang mempunyai manfaat bagi kesehatan. Perlu dilakukan percobaan lagi dengan menggunakan 
bahan baku lain seperti tepung beras, tepung jagung, tepung sukun, tepung talas dan lain-lain dengan menggunakan tepung ikan. Perlu dicari teknik atau cara memperoleh tepung ikan yang mempunyai aroma ikan tidak terlalu menyengat.

\section{RUJUKAN}

1. Departemen Kesehatan Dirjenbinkesmas. Pedoman Umum Pemberdayaan Masyarakat. Jakarta: Dirjenbinkesmas, 2008.

2. Departemen Kesehatan.Laporan Riset Kesehatan Dasar. Jakarta: Badan Litbang Kesehatan, 2005.

3. Lembaga IImu Pengetahuan Indonesia. Widya Karya Pangan dan Gizi, Jakarta: LIPI,2004.
4. Kementerian Kelautan dan Perikanan. Produksi Ikan di Indonesia. Jakarta: Kementerian Kelautan dan Perikanan, 2010.

5. Steinkraus, KH. Handbook of Indigenous Fermented Foods. Microbiology series, vol.12 .New York: Marcel Dekker, INC, 2006.

6. Van Veen, AG.Fermented and Dried Seafood Products in South East Asia.In "Fish as Food".Vol. III, G. Borgstorm (Ed). London: Academic Press,2003.

7. Espejo, JM.Philippine Handbook on Fish Processing Technology.Philippines:National Science Development Board, Bicutan, 2002

8. Machmud, MK, Dewi SS, Rossi RA.Komposisi Pangan Indonesia, Bogor: Puslitbang Gizi, 1990 
